\title{
AGRONOMIC PERFORMANCE OF IMPROVED MAIZE (Zea mays) CULTIVARS IN SOUTHERN CHAD
}

\section{Gapili Naoura $^{1 *}$, Nadjiam Djirabaye ${ }^{1}$, Hortense Noëlle Apala Mafouasson ${ }^{2}$, Mamahat Alhabib Hassane $^{1,3}$, Mbaidiro Taambaijim'dJosué ${ }^{1}$, Christian Yoguernan ${ }^{1}$, Foncha Felix ${ }^{2}$}

\author{
${ }^{1}$ Institut Tchadien de Recherche Agronomique pour le Développement (ITRAD), BP 5400 N'Djamena, Chad \\ ${ }^{2}$ Institute of Agricultural Research for Development (IRAD), BP 2123 Yaoundé, Cameroon \\ ${ }^{3}$ Equipe Génétique et Amélioration des plantes, Laboratoire Biosciences, Université Pr Joseph KI-ZERBO 03 BP 7021 , Ouagadougou, 03 , Burkina Faso.
}

Received - October 13, 2020; Revision - November 22, 2020; Accepted - December 24, 2020

Available Online - December 30, 2020

DOI: http://dx.doi.org/10.18006/2020.8(6).789.798

KEYWORDS
Maize
Grain yield
Adaptability
Cultivar release
Genotype xenvironment
interaction

interaction

\begin{abstract}
This study was carried out to identify high-performing maize cultivars adapted to the environmental conditions of Southern Chad. Twelve new cultivars associated with two local cultivars often used by farmers in Southern Chad were evaluated in three different environments in a randomized complete block design (RCBD) with three replications. The analysis of variance showed significant differences $(\mathrm{p}<0.001)$ between cultivars for the measured traits except for plant height $(\mathrm{p}=0.157)$ and ear height $(\mathrm{p}=0.624)$. Genotype $\times$ environment interaction was also reported significant among cultivars only for days to flowering and number of kernels per row, but yield did not show any statistical difference, although assessed cultivars differed in their relative main performance across the three sites. Potential grain yield showed a negative correlation with days to flowering, ear height, and days to silking. The study revealed different yield performances for the assessed cultivars across different environments. The cultivar 2013 TZEE WPOP DT STR was the highest yield producing cultivars at the combined sites. The cultivars IWD C2 SYN, TZEE WPOP DT C5 STR C5, 2011 TZE YDT STR SYN, and DTE STR YSYN POP C4 showed high-performance cultivars across the different environments and can be therefore recommended for release as new cultivars to farmers of Southern Chad.
\end{abstract}

* Corresponding author

E-mail: gapilinaoura@gmail.com (Gapili Naoura)

Peer review under responsibility of Journal of Experimental Biology and Agricultural Sciences.

Production and Hosting by Horizon Publisher India [HPI] (http://www.horizonpublisherindia.in/).

All rights reserved.
All the articles published by Journal of Experimental Biology and Agricultural Sciences are licensed under a Creative Commons Attribution-NonCommercial 4.0 International License Based on a work at www.jebas.org.

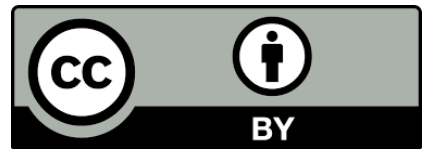




\section{Introduction}

Maize (Zea mays L.) also known as corn, is the only cereal crop of American origin that is cultivated in tropical and subtropical regions throughout the world (Mushtaq et al., 2016). It is one of the most important cereal crop and an important staple food for more than 1.2 billion people in Sub-Saharan Africa and Latin America (Fabunmi \& Balogun, 2015). Maize is an important cereal crop grown worldwide after wheat and rice, and it is the third most staple food crop in terms of cultivated area and production after sorghum and rice in Chad (DSP, 2019). Worldwide production of maize is 785 million tons and Africa produces $6.5 \%$ of this (Alhassan et al., 2016). In Chad, 341,872 ha area were grown with maize in 2018 and producing 436,215.63 tons with a yield of 1.29 t.ha $^{-1}$ (DSP, 2019). Maize is utilized in several ways such as popped, flour, mealed, animal feeds, as a source of sugar and oil, fermented, and eaten as a vegetable (Hancock, 1992).

In Chad, maize production increased from 117,978 tons with a yield of 1.146 tha $^{-1}$ in 2003 to 436,216 tons with a yield of 1.29 t.ha ${ }^{-1}$ in 2018 (DSP, 2019), which represents an increase of more than three times. However, this increase in production is mainly due to the extension of the cultivated area which is negatively affecting the environment. According to IRRI (1996), low crop yields will push people in many developing countries to extend cultivation onto marginal lands, thus aggravating the problem of how to sustain the natural resource base.

Climate change such as global warming is a major challenge to crop production, thus there is a need to identify possible ways that will improve crop yields by developing improved cultivars adapted to the changing environment (Kande et al., 2017). The ultimate goal of the plant breeder is to identify superior genotypes that can be released as a new cultivar to the farmer for commercial production (Acquaah, 2012).

In Chad, the improved varieties used by farmers were several years ago and abiotic stresses frequently constrain the growth and productivity of these old maize varieties. The local cultivars are largely adopted all over the country. Therefore testing the performance of new varieties in farmers' fields to be released as a cultivar is an important goal to enhance the productivity of maize in Southern Chad. Some new maize varieties from the International Institute of Tropical Agriculture (IITA) were received at Bébédjia Experimental Station in 2019, through the seed unit of ITRAD to include in their maize breeding programs and come out with improved varieties that will increase yields in farmers' fields of Chad. Genotypes $\times$ environment $(\mathrm{G} \times \mathrm{E})$ interaction is said to occur when two or more genotypes are compared across different environments and their relative performances (responses to the environment) differ (Bernardo, 2002; Acquaah, 2012). According to Bowman (2000), next to yield, $\mathrm{G} \times \mathrm{E}$ interactions have been identified as an important trait when selecting parents in a breeding programme.

This study was realized to test genotypes in three environments and to identify new superior varieties that can be released as new cultivars for commercial production through their registration in the National Catalogue of species and plant varieties of Chad.

\section{Materials et methods}

\subsection{Plant material}

A total of 14 maize varieties provided by the International Institute of Tropical Agriculture (IITA), Ibadan, Nigeria were used for this study (Table 1). Two of these varieties are already used by Chadian farmers and are considered here as local checks.

Table 1: Plant material used for the study

\begin{tabular}{|lc|}
\hline Code & Varieties \\
\hline V1 & 2009 TZE WDT STR (control 1) \\
\hline V2 & 2009 TZEE WSTR (control 2) \\
\hline V3 & 2011 TZE YDT STR SYN \\
\hline V4 & DTE STR YSYN POP C4 \\
\hline V5 & IWD C2 SYN \\
\hline V6 & PVA SYN 13 \\
\hline V7 & SMAZ \\
\hline V8 & SMAZ 39 \\
\hline V9 & SMAZ 52 \\
\hline V10 & TZE YPOP DT STR C4 \\
\hline V11 & TZEE WPOP DT C5 STR C5 \\
\hline V12 & TZEE YPOP DT STR C5 \\
\hline V13 & \\
\hline V14 & \\
\hline
\end{tabular}

\subsection{Experimental Site and Design}

The experiment was conducted at three different stations of the Chadian Institute of Agronomic Research for Development during the rainy season of 2019. These three experimental sites were, Bébédjia $\left(9^{\circ} 55^{\prime} \mathrm{N}\right.$ and $\left.15^{\circ} 8^{\prime} \mathrm{E}\right)$, Moussafoyo $\left(8^{\circ} 54^{\prime} 20^{\prime \prime} \mathrm{N}\right.$ and $\left.18^{\circ} 38^{\prime} 25.7^{\prime \prime E}\right)$, and Deli $\left(8^{\circ} 42^{\prime} \mathrm{N}\right.$ and $\left.15^{\circ} 52^{\prime} 60^{\prime \prime} \mathrm{E}\right)$. The previous crops were peanuts (Arachis hypogaea L.) in Bébédjia and Moussafoyo and cowpea (Vigna unguiculata L. Walp.) in Deli.

The experiment was laid out in a randomized complete block design (RCBD) with three replications. Each experimental plot 
consisted of three rows of $5 \mathrm{~m}$ long, with an inter-row spacing of $80 \mathrm{~cm}$ and intra-spacing of $30 \mathrm{~cm}(50$ plants per line). The space between plots, replications and blocks was maintained in all locations at $0.8 \mathrm{~m}, 2 \mathrm{~m}$, and $1.5 \mathrm{~m}$, respectively.

Seeds were sown on July 11, July 19, and July 23, 2019 at Bébédjia, Moussafoyo, and Deli sites respectively. Cultural practices were similar for all sites. Sowing was done manually and three weeks after emergence, plants were thinned to maintain a plant population of 41,667 plants per hectare. Immediately after thinning, $150 \mathrm{~kg} \mathrm{ha}^{-1}$ of NPK was applied to the field followed by an application of $50 \mathrm{~kg} \cdot \mathrm{ha}^{-1}$ of $\mathrm{N}$ approximately 6 weeks after sowing. Weed control was done mainly through hand hoeing and disease management was undertaken.

\subsection{Data Collection}

A total of 13 quantitative characters were observed throughout the growth cycle using CIMMYT's guideline for trial management (CIMMYT, 2014). Days to 50\% anthesis (DAT) and days to $50 \%$ silking (DAS) were recorded on a plot basis; and the rest of the observations were recorded on 10 randomly selected plants, in each replication. At the reproductive stage days to tasseling was taken as the number of days from sowing to when $50 \%$ of the plants just began to shed pollens; and days to silking which is the number of days from sowing to when silks just began emerging on $50 \%$ of the plants in the rows. Plant height $(\mathrm{PH})$, was recorded from ground level to the base of the tassel after the milky stage. Ear height (EH) was measured from ground level to the node bearing the uppermost ear after milky stage. Ear width (EW) and height of first ear (HFE) were measured after the milky stage. The number of ears harvested (NEH) in the middle row was recorded.

Number of kernel rows per ear (NKRE) was recorded by counting the number of kernel rows in the central part of the uppermost ear. Number of kernels per row (NKR) was recorded by counting the number of the kernel from each row. Thousand kernel weight (TKW), kernel weight per plot (KWP), and ear weight per plot (EWP) were weighed after gathering. The potential grain yield (PGY) was estimated by using kernel weight per plot.

\subsection{Data analysis}

The data were analyzed using the GenStat $12^{\text {th }}$ edition. All factors (variety, block, and environment) were treated as random variables.

Analysis of variance (ANOVA) was carried out to access the genotype and environment effect and their interaction, using Student-Newman-Keul's Method. The variation of each morphological trait was estimated using simple statistical measures: mean, minimum, maximum, and coefficient of variations. Repeatability $\left(h^{2}\right)$ was calculated for each site with a formula appropriate for unbalanced data sets (Piepho \& Mohring, 2007). The Pearson coefficients of correlation were used to determine the relationships between traits. Besides, principal component analysis (PCA) was conducted to determine the relationship among traits.

\section{Results}

\subsection{Weather condition}

The mean rainfall and temperature for the study sites during the experimental period are shown in Figure 1 below. For all assessed environments, flowering occurred around September and finished in October. During this time Deli was very wet (234.8 and $264.6 \mathrm{~mm}$ respectively for September and October) and average temperatures very cold ( 15 and $14.2{ }^{\circ} \mathrm{C}$ respectively for September and October).

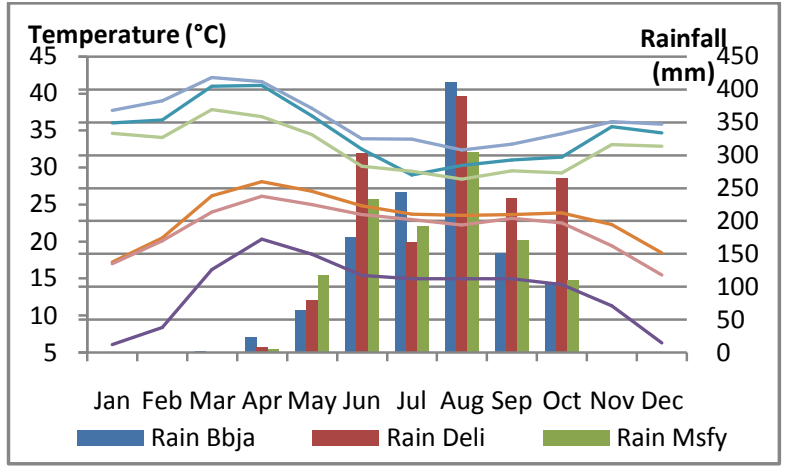

Figure 1 Weather conditions during the study period at the three study sites

\subsection{Analysis of variance and performance of assessed traits}

Analysis of variance using genotypes, location and interaction genotypes $\times$ location was performed (Table 2 ). Across the sites, almost all the assessed traits showed highly significant differences $(\mathrm{p}<0.001)$ among cultivars except days to $50 \%$ flowering which showed slight significant variation $(\mathrm{p}=0.013)$. Regarding the genotypic effect, most of the traits showed high significant variation $(\mathrm{p}<0.001)$. Further, two traits (ear girth and number of kernel per row) showed slight significant variations while two traits (plant height and ear height) showed no significant differences among cultivars. The effect of interaction between genotype and environment showed a highly significant difference $(\mathrm{p}<0.001)$ among cultivars for day to $50 \%$ silking and slight significant differences $(\mathrm{p}=0.021)$ for the number of kernels per row, while rest of the traits showed no significant difference among cultivars.

The repeatability estimates $\left(\mathrm{h}^{2}\right)$ varied from $8.03 \%$ for days to $50 \%$ flowering to $99.43 \%$ for plant height. The assessed traits had almost very high $h^{2}(\geq 95.9$ ) except days to $50 \%$ flowering which had the lowest $h^{2}$. 
Table $2 \mathrm{P}$-value Analysis from analysis of variance for assessed traits

\begin{tabular}{|cc|ccc|}
\hline Characters & Site & Variety & Site x Variety & Repeatability $(h)^{2} \%$ \\
\hline Ear girth $(\mathrm{cm})$ & $<0.001^{* * *}$ & $0.038^{*}$ & 0.684 & 98.64 \\
\hline Height of first ear $(\mathrm{cm})$ & $<0.001^{* * *}$ & $<0.001^{* * *}$ & 0.310 & 97.65 \\
\hline Plant height $(\mathrm{cm})$ & $<0.001^{* * *}$ & $0.157^{\mathrm{ns}}$ & 0.173 & 99.43 \\
\hline Ear height $(\mathrm{cm})$ & $<0.001^{* * *}$ & $0.624^{\mathrm{ns}}$ & 0.855 & 98.54 \\
\hline Number of ears per plot & $<0.001^{* * *}$ & $<0.001^{* * *}$ & 0.236 & 96.23 \\
\hline Days to 50\% silking (days) & $<0.001^{* * *}$ & $<0.001^{* * *}$ & $<0.001^{* * *}$ & 8.03 \\
\hline Day to 50\% flowering (days) & $0.013^{*}$ & $<0.001^{* * *}$ & 0.221 & 99.24 \\
\hline Number of kernels per row & $<0.001^{* * *}$ & $0.023^{*}$ & $0.021^{*}$ & 96.33 \\
\hline Number of kernel row per ear & $<0.001^{* * *}$ & $<0.001^{* * *}$ & 0.797 & 97.85 \\
\hline Kernel weight per plot $(\mathrm{g})$ & $<0.001^{* * *}$ & $<0.001^{* * *}$ & 0.060 & 97.84 \\
\hline Ear weight per plot $(\mathrm{g})$ & $<0.001^{* * *}$ & $<0.001^{* * *}$ & 0.082 & 97.85 \\
\hline Potential grain yield (t.ha $\left.{ }^{-1}\right)$ & $<0.001^{* * *}$ & $<0.001^{* * *}$ & 0.060 & \\
\hline
\end{tabular}

Table 3 Agronomic and phenotypic performances of varieties evaluated for the whole site

\begin{tabular}{|cccccccc|}
\hline Traits & Min. & Max. & Mean & CV & F $>$ F \\
\hline Days to 50\% flowering (days) & 51.44 & 61.56 & $57.22 \pm 3.41$ & 5.97 & 23.324 & $<0.0001$ \\
\hline Days to 50\% silking (days) & 55 & 63.78 & $60.14 \pm 2.92$ & 4.86 & 2.642 & 0.018 \\
\hline Plant height (cm) & 157.46 & 179.13 & $169.13 \pm 5.65$ & 3.34 & 0.091 & 0.900 \\
\hline Height of first ear (cm) & 46.33 & 67 & $57.67 \pm 6.25$ & 10.84 & 1.027 & 0.458 \\
\hline Ear height (cm) & 11.44 & 15.93 & $12.88 \pm 1.21$ & 9.42 & 0.233 & 0.996 \\
\hline Ear girth (cm) & 11.65 & 14.12 & $12.36 \pm 0.67$ & 5.45 & 0.457 & 0.929 \\
\hline Number of kernels row per ear & 12.01 & 15.17 & $12.89 \pm 0.87$ & 6.74 & 2.331 & 0.030 \\
\hline Number of kernel per row & 18.77 & 38.19 & $27.05 \pm 5.50$ & 20.34 & 0.195 & 0.998 \\
\hline Thousand kernels weight (g) & 112.9 & 211.8 & $145.1 \pm 29.7$ & 20.49 & 1.457 & 0.196 \\
\hline Ears weight per plot (g) & 797 & 1463.8 & $1159.4 \pm 197.9$ & 17.07 & 2.516 & 0.020 \\
\hline Kernels weight per plot (g) & 543.5 & 1147.3 & $753.4 \pm 156.6$ & 20.78 & 2.524 & 0.020 \\
\hline Potential grain yield (t.ha $\left.{ }^{-1}\right)$ & 1.36 & 2.87 & $1.88 \pm 0.39$ & 20.99 & 2.524 & 0.020 \\
\hline
\end{tabular}

Analysis of the performance of assessed traits showed that the coefficient of variation (CV) ranged from 3.34 (plant height) to 20.99 (potential grain yield) for the combined site of evaluation (Table 3). The computed CV for eight of the 12 traits ranged from 3.34 to $17.07 \%$. However, grain yield had the highest CV of 20.99 $\%$, followed by kernels weight per plot $(20.78 \%)$, thousand kernels weight $(20.49 \%)$, and the number of kernels per row (20.34\%).

The analysis of mean values of traits summarized in table 3 revealed that days to $50 \%$ tasseling and silking ranged from 51.44 to 61.56 days respectively and from 55 to 63.78 days. Plant height varied from 157.46 to $179.13 \mathrm{~cm}$ with an average of $169.13 \pm 5.65$ $\mathrm{cm}$; however, it showed no significant difference among tested varieties. Potential grain yield showed a slightly significant difference among assessed varieties and ranged from 1.36 to 2.87 t.ha $^{-1}$, with an average of $1.88 \pm 0.39$ t.ha $^{-1}$.

Table 4 summarizes the performances of assessed traits in each site of evaluation. Results showed that traits performed differently from one study site to another. Thus higher means of potential grain yield was obtained in the Bébédjia site $(2.4$ t.ha $\left.{ }^{-1}\right)$, followed by Moussafoyo $\left(2.2\right.$ t.ha $\left.^{-1}\right)$, while the lowest 
Table 4 Agronomic and phenotypic performances of cultivars evaluated per site

\begin{tabular}{|c|c|c|c|c|c|c|c|c|c|c|c|c|}
\hline \multirow{2}{*}{ Traits } & \multicolumn{4}{|c|}{ Bébédjia } & \multicolumn{4}{|c|}{ Deli } & \multicolumn{4}{|c|}{ Moussafoyo } \\
\hline & Min & Max & Mean & $\mathrm{CV}$ & Min & $\operatorname{Max}$ & Mean & $\mathrm{CV}$ & Min & Max & Mean & $\mathrm{CV}$ \\
\hline DAT & 51 & 62 & $57 . \pm 3.6$ & 6.3 & 50.7 & 62 & $57.1 \pm 3.6$ & 6.4 & 52.7 & 62 & $58.2 \pm 3.2$ & 5.5 \\
\hline DAS & 51.7 & 62 & $57.6 \pm 3.5$ & 6.1 & 58 & 66.7 & $62.5 \pm 2.5$ & 4.0 & 58 & 64.7 & $61.3 \pm 2.7$ & 4.3 \\
\hline $\mathrm{PH}$ & 174.3 & 207.3 & $190.4 \pm 10$ & 5.5 & 111.2 & 144.4 & $127.4 \pm 9$ & 7.2 & 173.6 & 199.4 & $186.4 \pm 7$ & 4.0 \\
\hline EH & 12.45 & 18.4 & $16.3 \pm 1.6$ & 9.6 & 7.6 & 13.1 & $9.5 \pm 1.5$ & 15.5 & 10.2 & 13.9 & $12.1 \pm 1.0$ & 8.0 \\
\hline EW & 12.4 & 14.1 & $13.5 \pm 0.5$ & 3.4 & 9.9 & 12.7 & $10.8 \pm 0.9$ & 7.9 & 11.8 & 13.7 & $12.5 \pm 0.5$ & 4.1 \\
\hline NKRE & 12.7 & 15.6 & $13.7 \pm 0.9$ & 6.2 & 11.3 & 13.6 & $12.1 \pm 0.7$ & 5.7 & 11.6 & 14 & $12.5 \pm 0.6$ & 5.0 \\
\hline NKR & 27.6 & 33.7 & $30.1 \pm 1.8$ & 6.1 & 11.2 & 63.3 & $32.3 \pm 16$ & 49.3 & 15.4 & 25.1 & $18.7 \pm 2.7$ & 14.4 \\
\hline PGY & 1.2 & 3.5 & $2.4 \pm 0.6$ & 23.3 & 0.3 & 1.5 & $0.8 \pm 0.3$ & 37.2 & 1.6 & 2.8 & $2.2 \pm 0.4$ & 17.9 \\
\hline
\end{tabular}

DAT: days to 50\% anthesis; DAS: days to 50\% silking; PH: plant height; EH: ear height; EW: ear width; NKRE: number of kernel row per ear; NKR: number of kernels per row; PGY: potential grain yield.

Table 5 Pearson correlation coefficient between traits evaluated

\begin{tabular}{|c|c|c|c|c|c|c|c|c|c|c|}
\hline Traits & DAT & DAS & PH & HFE & $\mathrm{EH}$ & EW & NKRE & TKW & EWP & KWP \\
\hline DAS & $0.963^{* * *}$ & & & & & & & & & \\
\hline $\mathrm{PH}$ & 0.253 & 0.075 & & & & & & & & \\
\hline HFE & $0.820^{* * *}$ & $0.782^{* * * *}$ & 0.338 & & & & & & & \\
\hline $\mathrm{EH}$ & -0.305 & $-0.513^{* *}$ & 0.696 & -0.251 & & & & & & \\
\hline EW & -0.077 & -0.264 & $0.573^{* *}$ & -0.189 & $0.784^{* * * *}$ & & & & & \\
\hline NKRE & 0.104 & -0.072 & $0.656^{* *}$ & -0.078 & $0.654^{* *}$ & $0.899^{* * *}$ & & & & \\
\hline TKW & $-0.433^{*}$ & $-0.584^{* *}$ & 0.180 & $-0.380^{*}$ & $0.550^{* * *}$ & $0.606^{* *}$ & $0.419^{*}$ & & & \\
\hline EWP & -0.295 & -0.369 & 0.253 & -0.164 & 0.270 & 0.341 & 0.345 & 0.390 & & \\
\hline KWP & $-0.490^{*}$ & $-0.636^{* *}$ & $0.401^{*}$ & $-0.410^{*}$ & $0.612^{* *}$ & $0.607^{* *}$ & $0.601^{* *}$ & $0.676^{* *}$ & $0.829^{* * * *}$ & \\
\hline PGY & $-0.496^{*}$ & $-0.642^{* *}$ & 0.389 & $-0.421^{*}$ & $0.613^{* * *}$ & $0.605^{* *}$ & $0.597^{* *}$ & $0.677^{* *}$ & $0.825^{* * *}$ & $1^{* * * *}$ \\
\hline
\end{tabular}

DAT: days to 50\% anthesis; DAS: days to 50\% silking; PH: plant height; HFE: height of the first ear; EH: ear height; EW: ear width; NKRE: number of kernel row per ear; TKW: thousand kernel weight; EWP: ear weight per plot; KWP: kernels weight per plot; PGY: potential grain yield; statistical significant: ${ }^{*} \mathrm{p}<0.05 ; * * \mathrm{p}<0.01 ; * * * \mathrm{p}<0.001$.

means of potential grain yield was observed in Deli and it was less than one tons per hectare $\left(0.8 \mathrm{t}^{\mathrm{h}} \mathrm{ha}^{-1}\right)$. The potential grain yield ranged from 1.2 to 3.5 t.ha $^{-1}$; 1.6 to 2.8 t.ha $^{-1}$ and 0.3 to 1.5 t.ha $^{-1}$ for Bébédjia, Moussafoyo, and Deli regions respectively.

Coefficients of variations (CV) varied slightly across sites and in all sites; potential grain yield sowed highest CV; 37.2\%, 23.3\%, and $17.9 \%$ for Deli, Bébédjia, and Moussafoyo respectively. The rest of the traits showed slight differences in $\mathrm{CV}$ for all the three study sites except for the number of kernels per row from Deli which showed a high CV (49.3\%).

\subsection{Correlation among assessed traits}

Pearson correlation coefficients ( $r$ ) of the ten traits are presented in table 5. Potential grain yield showed a negative correlation with day to flowering $(\mathrm{r}=-0.496, \mathrm{p}<0.05)$; the height of the first ear $(\mathrm{r}=-0.421, \mathrm{p}<0.05)$, and day to silking $(\mathrm{r}=-0.62, \mathrm{p}<0.01)$. PGY was positively correlated with ear height $(\mathrm{r}=0.613, \mathrm{p}<0.01)$; ear width $(\mathrm{r}=0.605, \mathrm{p}<0.01)$; thousand kernel weight $(\mathrm{r}=0.825$, $\mathrm{p}<0.001)$ and kernel weight per plot $(\mathrm{r}=1, \mathrm{p}<0.001)$. Flowering time was also strongly and positively correlated with silking time $(r=0.963 ; p<0.001)$ and height of the first ear $(r=0.820, p<0.001)$. Further, the height of first ear was negatively correlated with 
kernel weight per plot $(\mathrm{r}=-0.410, \mathrm{p}<0.05)$ and thousand kerne weight $(\mathrm{r}=-0.380, \mathrm{p}<0.05)$.

\subsection{Principal Component Analysis of traits}

The assessed traits were subjected to principal component analysis (PCA), which revealed that the three most important PCs, with Eigenvalue $>1$ contributed to $48.940 \%, 24.028 \%$, and $9.371 \%$ of the total variation (Table 6). The most important traits in PCs 1 were kernel weight per plot, potential grain yield, ear height, ear width, and thousand kernel weight, which are positively associated with PC 1. Days to 50\% tasseling day to 50\% silking and height of first ear insertion had a negative factor loading on PC1. PC2 was positively related to days to $50 \%$ tasseling, days to $50 \%$ silking, plant height, the height of first ear insertion, and the number of kernel rows per ear. This axe was strongly associated with late maturing plants with high biomass. Ear weight and the number of kernels per row were the traits that contributed most positively to PC3. On the other hand, ear height, ear width, and number kernel row per ear were negatively contributed to the PC3.

Table 6: Eigenvalue and proportions of variability as assessed by traits contributed to three PCs

\begin{tabular}{|lccc|}
\hline & PC1 & PC2 & PC3 \\
\hline Eigen value & 5.873 & 2.883 & 1.124 \\
\hline Proportion of variance (\%) & 48.940 & 24.028 & 9.371 \\
\hline Days to 50\% anthesis & 48.940 & 72.968 & 82.339 \\
\hline Days to 50\% silking & -0.220 & 0.470 & 0.065 \\
\hline Plant height & -0.291 & 0.379 & 0.077 \\
\hline Height of first ear insertion & 0.192 & 0.427 & -0.118 \\
\hline Ear height & -0.196 & 0.443 & 0.281 \\
\hline Ear width & 0.331 & 0.150 & -0.356 \\
\hline Number of kernel row per ear & 0.284 & 0.325 & -0.219 \\
\hline Number of kernel per row & 0.143 & 0.261 & 0.317 \\
\hline Thousand kernels weight & 0.316 & -0.061 & -0.069 \\
\hline Ear weight per plot & 0.275 & -0.011 & 0.587 \\
\hline Kernels weight per plot & 0.390 & -0.014 & 0.280 \\
\hline Potential grain yield & 0.390 & -0.019 & 0.279 \\
\hline
\end{tabular}

3.5 Agronomic and phenotypic performance of the fourteen varieties

The average performance of cultivars in the combined sites permitted us to see the significant differences between various cultivars for DAT $(\mathrm{p}<0.001)$, DAS $(<0.001)$, NKRE $(<0.001)$, EWP $(p=0.040)$ KWP $(p=0.046)$, and PGY $(p=0.046)$. However, for the traits $\mathrm{PH}, \mathrm{EH}, \mathrm{EW}$, and TKW, there were no significant differences ( $p>0.05)$ among cultivars.

Cultivars IWD C2 SYN had the latest day to flowering (61.56 days) while the cultivar TZEE YPOP DT STR C5 had the earliest flowering (51.44 days). Further, Cultivars TZEE WPOP DT C5 STR C5 had the highest weight of thousand kernels (234.9 g) this was followed by cultivar DTE STR YSYN POP C4(222.37 g) while the cultivar PVA SYN 13 had the lower thousand kernels weight (180.53 g).

Results of this study revealed that cultivar 2013 TZEE WPOP DT STR recorded the highest yields $\left(2.87\right.$ t.ha $\left.^{-1}\right)$, likely because it had the early flowering time (53 days) less than the mean (57.2 \pm 3.4 days), the highest number of kernels row per ear (15.17) and highest kernel weight per plot (1147.3 g). Cultivar 2013 TZEE WPOP DT STR was followed by cultivar DTE STR YSYN POP C4 with 2.37 t.ha $^{-1}$ and cultivar 2011 TZE YDT

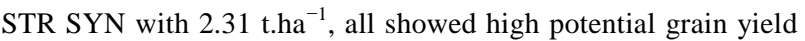
than the two local checks 2009 TZE WDT STR and 2009 TZEE WSTR which had respectively 2.21 and $1.95 \mathrm{t}^{-\mathrm{ha}^{-1}}$.

Although there were no significant differences between cultivars for plant height $(\mathrm{p}=0.990)$, ear height $(\mathrm{p}=0.919)$, and ear width $(\mathrm{p}=0.365)$, the best yielding cultivar was the 2013 TZEE WPOP. DT STR, showed the highest value for the above mentioned traits. Regarding the combining results for all study sites, the variety 2013 TZEE WPOP DT STR was the best choice for producing in farmers' fields.

Performance of varieties regarding yield (PGY) and yield components (EH and EW) differed between site and significant genotypes $\mathrm{x}$ site interactions effects were detected. The means of EH, EW, and PGY were higher in Bébédjia, followed by Moussafoyo while Deli showed the lower means.

In Bébédjia the two local checks (2009 TZE WDT STRand2009 TZEE WSTR) showed the grain yield (2.433 and 2.75t.ha ${ }^{-1}$ respectively) but this was lower than the cultivar DTE STR YSYN POP C4 (3.458 t.ha $\left.{ }^{-1}\right), 2011$ TZE YDT STR SYN(3.032 t.ha $\left.{ }^{-1}\right)$ and 2013 TZEE WPOP DT STR(2.868 t.ha $\left.{ }^{-1}\right)$.

In Deli the cultivar TZE YPOP DT STR C4 showed the highest grain yield $\left(1.5\right.$ t.ha $\left.^{-1}\right)$ followed by IWD C2 SYN (1.424 t.ha $\left.{ }^{-1}\right)$ while the local check 2009 TZE WDT STR and TZEE WPOP DT C5 STR C5 produced $1.411 \mathrm{t} . h a^{-1}$ each. The two local checks 2009 TZE WDT STR and 2009 TZEE WSTR showed grain yield (1.411 t.ha ${ }^{-1}$ and 1.325 t.ha $^{-1}$ respectively) which was less than the TZEE WPOP DT C5 STR C5 cultivar (1.74 t.ha $\left.{ }^{-1}\right)$. 


\begin{tabular}{|c|c|c|c|c|c|c|c|c|c|c|}
\hline Var & DAT & DAS & PH & $\mathrm{EH}$ & EW & NKRE & EWP & KWP & TKW & PGY \\
\hline V1 & 54.72 & 58.22 & 164.84 & 12.45 & 12.52 & 12.53 & 1068.12 & 885.49 & 211.8 & 2.21 \\
\hline $\mathrm{V} 2$ & 53.44 & 57.78 & 157.46 & 11.55 & 11.84 & 12.33 & 945.02 & 778.79 & 214.6 & 1.95 \\
\hline V3 & 55.44 & 58.67 & 166.69 & 12.95 & 12.17 & 12.72 & 1127.71 & 924.32 & 220.63 & 2.31 \\
\hline V4 & 53 & 55 & 179.13 & 15.93 & 14.12 & 15.17 & 1380.33 & 1147.33 & 206.63 & 2.87 \\
\hline V5 & 55.44 & 58.44 & 172.52 & 13.3 & 11.95 & 12.01 & 1185.91 & 947.12 & 222.37 & 2.37 \\
\hline V6 & 61.56 & 63.78 & 174.62 & 13.11 & 13.22 & 14.38 & 1147.79 & 885.26 & 190.07 & 2.21 \\
\hline V7 & 59.67 & 62.67 & 161.94 & 11.44 & 12.41 & 12.68 & 997.58 & 759.69 & 188.53 & 1.90 \\
\hline V8 & 61.22 & 63.67 & 171.41 & 12.09 & 11.82 & 12.82 & 790.49 & 634.14 & 180.53 & 1.59 \\
\hline V9 & 60.78 & 63.56 & 174.6 & 12.11 & 12.14 & 12.83 & 904.02 & 712.69 & 204.27 & 1.78 \\
\hline V10 & 60 & 61.78 & 171.23 & 12.89 & 12.08 & 12.98 & 1012.63 & 798.89 & 206.27 & 2.00 \\
\hline V11 & 60.44 & 63.22 & 166.69 & 11.94 & 11.74 & 12.31 & 787.52 & 638.89 & 182.93 & 1.60 \\
\hline V12 & 57.89 & 60.11 & 171.04 & 14.58 & 12.88 & 12.79 & 675.47 & 553.67 & 216.3 & 1.38 \\
\hline V13 & 56 & 58.22 & 169.77 & 13.53 & 12.44 & 12.89 & 1052.27 & 854.49 & 234.9 & 2.14 \\
\hline V14 & 51.44 & 56.89 & 165.82 & 12.48 & 11.65 & 12.02 & 940.87 & 701.53 & 209.7 & 1.75 \\
\hline Min & 51.44 & 55 & 157.46 & 11.44 & 11.65 & 12.01 & 675.47 & 553.67 & 180.53 & 1.38 \\
\hline Max & 61.56 & 63.78 & 179.13 & 15.93 & 14.12 & 15.17 & 1380.33 & 1147.33 & 234.9 & 2.87 \\
\hline Mean & $57.2 \pm 3.4$ & $60.1 \pm 2.9$ & $169 \pm 5.6$ & $12.9 \pm 1.2$ & $12.4 \pm 0.7$ & $12.9 \pm 0.9$ & $1001 \pm 182.9$ & $801 \pm 154.1$ & $206 \pm 15.9$ & $2 \pm 0.4$ \\
\hline $\mathrm{CV}$ & 5.97 & 4.86 & 3.34 & 9.42 & 5.45 & 6.74 & 18.27 & 19.23 & 7.70 & 19.23 \\
\hline $\operatorname{Pr}>F$ & $<0.001$ & $<0.001$ & 0.990 & 0.919 & 0.365 & $<0.001$ & 0.04 & 0.046 & 0.196 & 0.046 \\
\hline
\end{tabular}

DAT: days to 50\% anthesis; DAS: days to 50\% silking; PH: Plant height; EH: ear height; EW: ear width; NKRE: number of kernels row per ear; EWP: ear weight per plot; KWP: Kernel weight per plot; TKW: thousand kernel weight; PGY: potential grain yield; Var: varieties; Min.: minimal; Max.: maximal; CV: coefficient of variation; V1: 2009 TZE WDT STR; V2: 2009 TZEE WSTR; V3: 2011 TZE YDT STR SYN; V4: 2013 TZEE WPOP DT STR; V5: DTE STR YSYN POP C4; V6: IWD C2 SYN; V7: IWDC3 SYN /White DT STR SYN; V8: PVA SYN 13; V9: SMAZ; V10: SMAZ 39; V11: SMAZ 52; V12: TZE YPOP DT STR C4; V13: TZEE WPOP DT C5 STR C5; V14: TZEE YPOP DT STR C5

Table 8 Yield and yield components for the fourteen cultivars regarding the environmental effect

\begin{tabular}{|c|c|c|c|c|c|c|c|c|c|}
\hline \multirow{2}{*}{ Varieties } & \multicolumn{3}{|c|}{ Bébédjia } & \multicolumn{3}{|c|}{ Deli } & \multicolumn{3}{|c|}{ Moussafoyo } \\
\hline & EH & EW & PGY & $\mathrm{EH}$ & EW & PGY & $\mathrm{EH}$ & EW & PGY \\
\hline V1 & 15.867 & 13.447 & 2.433 & 9.319 & 11.424 & 1.411 & 12.167 & 12.7 & 2.798 \\
\hline $\mathrm{V} 2$ & 16.8 & 13.107 & 2.75 & 7.643 & 10.371 & 1.325 & 10.219 & 12.028 & 1.766 \\
\hline V3 & 17.9 & 13.523 & 3.032 & 9.036 & 10.725 & 1.251 & 11.908 & 12.259 & 2.650 \\
\hline V4 & 15.933 & 14.117 & 2.868 & - & - & - & - & - & - \\
\hline V5 & 18.4 & 13.533 & 3.458 & 9.533 & 10.15 & 1.294 & 11.967 & 12.167 & 2.351 \\
\hline V6 & 16.6 & 13.733 & 2.383 & 9.675 & 12.208 & 1.424 & 13.05 & 13.717 & 2.832 \\
\hline V7 & 14.583 & 13.75 & 2.168 & 9 & 10.867 & 1.411 & 10.75 & 12.6 & 2.118 \\
\hline V8 & 12.45 & 13.267 & 1.766 & 11.233 & 10.189 & 1.223 & 12.583 & 12 & 1.767 \\
\hline V9 & 17.067 & 13.917 & 2.122 & 7.671 & 10.067 & 1.051 & 11.583 & 12.45 & 2.173 \\
\hline V10 & 15.667 & 13.593 & 2.554 & 10.007 & 9.911 & 1.124 & 13 & 12.75 & 2.313 \\
\hline V11 & 15.117 & 12.4 & 2 & 8.772 & 10.683 & 0.888 & 11.917 & 12.15 & 1.903 \\
\hline V12 & 16.711 & 13 & 1.178 & 13.1 & 12.667 & 0.939 & 13.923 & 12.967 & 2.036 \\
\hline V13 & 17.867 & 13.947 & 2.448 & 10.4 & 10.533 & 1.738 & 12.317 & 12.85 & 2.224 \\
\hline V14 & 17.4 & 13.06 & 2.566 & 8.442 & 10.075 & 1.096 & 11.583 & 11.826 & 1.6 \\
\hline Min & 12.45 & 12.4 & 1.178 & 7.643 & 9.911 & 0.888 & 10.219 & 11.826 & 1.6 \\
\hline $\operatorname{Max}$ & 18.4 & 14.117 & 3.458 & 13.100 & 12.667 & 1.738 & 13.923 & 13.717 & 2.832 \\
\hline Mean & $16.3 \pm 1.6$ & $13.5 \pm 0.5$ & $2.4 \pm 0.6$ & $9.5 \pm 1.5$ & $10.8 \pm 0.9$ & $1.2 \pm 0.2$ & $12.1 \pm 1$ & $12.5 \pm 0.5$ & $2.2 \pm 0.4$ \\
\hline$C V$ & 9.562 & 3.399 & 23.320 & 15.451 & 7.942 & 18.487 & 8.035 & 4.102 & 17.903 \\
\hline $\operatorname{Pr}>F$ & 0.146 & 0.118 & 0.025 & 0.006 & 0.421 & 0.045 & $<0.001$ & 0.056 & 0.079 \\
\hline
\end{tabular}

EH: ear height; EW: ear width; PGY: potential grain yield; V1: 2009 TZE WDT STR; V2: 2009 TZEE WSTR; V3: 2011 TZE YDT STR SYN; V4: 2013 TZEE WPOP DT STR; V5: DTE STR YSYN POP C4; V6: IWD C2 SYN; V7: IWDC3 SYN /White DT STR SYN; V8: PVA SYN 13; V9: SMAZ; V10: SMAZ 39; V11: SMAZ 52; V12: TZE YPOP DT STR C4; V13: TZEE WPOP DT C5 STR C5; V14: TZEE YPOP DT STR C5

Journal of Experimental Biology and Agricultural Sciences http://www.jebas.org 
In Moussafoyo, the highest yielding cultivar was IWD C2 SYN, which produced $2.832 \mathrm{t}^{-h^{-1}}$, followed by the local check cultivar 2009 TZE WDT STR with a production of 2.798 t.ha ${ }^{-1}$. Regarding the second local check (2009 TZEE WSTR) which produced 1.766 t.ha $^{-1}$, the cultivars 2011 TZE YDT STR SYN and DTE STR YSYN POP C4 produced respectively 2.650 and 2.351 t.ha $^{-1}$, showing high performances and could not be neglected in choice of news cultivar to be released.

\section{Discussion}

Assessment of new cultivars of maize in Southern Chad maize basin to increase the yield of maize in this part of the country was the purpose of this study. Twelve news cultivars were tested in association with two better known cultivars produced in this zone for around 10 years. The weather conditions in the three environments involved in this study were different and the response of cultivars of each environment varied significantly. Rainfall in Deli was highest while in the case of Bébédjia and Moussafoyo, it was almost at par. These last two environments (Bébédjia and Moussafoyo) increased the yield and yield components of assessed cultivars than the Deli environment though the last environment was most wet. Weather conditions during this experiment were different across sites; Deli was wetter with 1451.6 $\mathrm{mm}$ of rainfall. In fact, at the end of September and the beginning of October rain was highly concentrated, damaging flowering which occurred at this time.

Analysis of variance of assessed traits showed highly significant differences among cultivars and sites. Similarly, Okoli \& Nworji (2020) also observed significant variation among maize genotypes for all assessed traits. The interaction between genotype $\times$ environment was significant for most of the traits and significant variation was found for days to $50 \%$ silking $(\mathrm{p}<0.001)$ and the number of kernels per row $(\mathrm{p}=0.021)$. Although yield and yield components showed no significant variation, their values observed in the three sites varied enough. As said previously by Acquaah (2012) $\mathrm{G} \times \mathrm{E}$ interaction occurs when one genotype consistently performs better than the other genotypes by about the same amount across all the environments included in the test. The average grain yield in Bébédjia, Deli, and Moussafoyo ranged from 1.2 to 3.5 t.ha $^{-1} ; 0.3$ to 1.5 t.ha $^{-1}$, and 1.6 to 2.8 t.ha $^{-1}$ respectively. According to Jackson et al. (1996), the yield is a quantitative trait under multiple genetic controls and is characterized by low heritability and high genotype-by-environment interaction.

The coefficient of variation is a measure of the relative variability of a given population (Araus et al., 2009; Acquaah, 2012). The study revealed that yield components also contribute to higher yield. On the contrary, some traits like late flowering time and late silking time decreased yield and yield components. The late tasseling cultivars had a late silking time and the position of the first ear was high from the soil. The late emergence of the first ear decreased kernel weight and the thousand kernel weight. According to Ige et al. (2019), correlations had been used as an effective tool to determine the relationships among agronomic traits in genetically diverse populations for enhanced progress in crop improvement. The study realized by Aristil et al. (2019) showed a strong and direct correlation between yield and ear weight and an inverse correlation between yield and male \& female flowering day after sowing.

Principal component analysis (PCA) showed the first PC was associated with potential grain yield, kernels weight per plot, thousand kernel weights, ear girth, and plant height. These traits were negatively associated with tasseling and silking time and height of first ear insertion. The second PC put together tasseling and silking time, plant height, the height of first ear insertion, and the number of kernels row per ear. The last PC was positively associated with ear weight and the number of kernels per row and negatively associated with the number of kernel row per ear and ear width and height. According to Goldman (2018), PCA can be very helpful in visualizing the relationship among samples for multiples flavor attributes at the same time, as well as for visualizing the correlations among attributes and the importance of different attributes in determining differences among samples.

Analysis of the performance of assessed cultivars in the combined site showed that 2013 TZEE WPOP DT STR had the highest grain yield $\left(2.87\right.$ t.ha $\left.^{-1}\right)$, followed by cultivars DTE STR YSYN POP C4 and 2011 TZE YDT STR SYN which produced 2.37 and 2.31 t.ha $^{-1}$ respectively. These three cultivars were higher than the two local checks used for comparison and the difference among them was statically significant $(\mathrm{p}<0.046)$. The number of days to tasseling for these varieties was earlier than the mean value (57.3 \pm 3.4 days). A study conducted in Cameroon showed that hybrids yielded more than $3500 \mathrm{~kg} \cdot \mathrm{ha}^{-1}$ under low $\mathrm{N}$ conditions (Mafouasson et al., 2017). Maize is a cross-pollinated species that show high heterosis (Betran et al., 2003), similarly, Naitormmbaide et al. (2015) already tested these two cheks in Bébédjia in 2011 and showed a yield of about around 4 t.ha ${ }^{-1}$. Some studies performed by Aristil et al. (2019), Okoli \& Nworji (2020) found that grain yield ranged from 3.6 to 5.0 t.ha $^{-1}$ and from 1.18 to 3.63 t.ha ${ }^{-1}$ respectively.

The yield and yield components differed across environments and showed slight G X E interactions. Although the average yield of the 14 cultivars was higher in Bébédjia (Average 2.4 t.ha $^{-1}$ which varied from 1.178 to $3.458 \mathrm{t} . h a^{-1}$ ) than Moussafoyo (Average 2.2 t.ha $^{-1}$ which ranged from 1.6 to 2.832 t.ha $^{-1}$ ) and Deli (Average 1.2 t.ha $^{-1}$

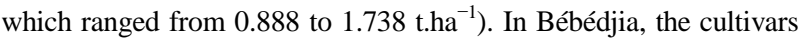
DTE STR YSYN POP C4, 2011 TZE YDT STR SYN, and 2013 TZEE WPOP DT STR yielded 3.458, 3.032, and 2.868 t.ha $^{-1}$ respectively, and these are higher than the two local checks used for 
comparison. On the other hand cultivars TZEE YPOP DT STR C5 and TZEE WPOP DT C5 STR C5 showed higher grain yield (respectively 2.566 and 2.448 t.ha $^{-1}$ ) than the one-word control, cultivar 2009 TZE WDT STR which produced 2.433 t.ha $^{-1}$, but was less productive than 2009 TZEE WSTR $\left(2.75\right.$ t.ha $\left.^{-1}\right)$.

To release these news varieties to farmers for commercial production, some superior varieties identified should be tested in farmers' fields, take into account the variation of environment. The cultivar IWD C2 SYN seemed to show superiority in all environments and could be evaluated in farmers' fields associated with cultivars 2013 TZEE WPOP DT STR, 2011 TZE YDT STR SYN, DTE STR YSYN POP C4, and TZE YPOP DT STR C4. This evaluation should be carried out with participatory selection which helps the breeders to include the farmers' choices in their breeding programme before coming out with new varieties. According to Ceccarelli et al. (2000), decentralized selection is a powerful methodology to fit crops to the physical environment. Farmers' participation in the selection of new varieties has been the ultimate conceptual consequence of a positive interpretation of genotype $\times$ environment interactions, that is, of breeding for specific adaptation. The farmers' participation in the breeding program has been shown to enhance the breeding procedure for specific environmental adaptation (Cecceralli, 2009).

\section{Conclusion}

This study was conducted to identify the high performance varieties to be released in farmers' fields regarding multiple environments. All assessed varieties were early maturing with the number of days to $50 \%$ tasseling ranging between 51 to 61 days and cultivar TZEE YPOP DT STR C5 had the earliest flowering time of 51 days, followed by cultivar 2013 TZEE WPOP DT STR with 53 days. Some cultivars IWD C2 SYN, TZEE WPOP DT C5 STR C5, 2011 TZE YDT STR SYN, DTE STR YSYN POP C4 and 2013 TZEE WPOP DT STR were identified superior to well-known varieties 2009 TZE WDT STR and 2009 TZEE WSTR in station and farm could be tested, next growing season in field trials including variable environments. Farmer should be involved during this process through participatory selection.

\section{Acknowledgement}

The authors would like to thank Dimlelngar Marc and Ganezouné Michel for field management and data collected.

\section{Conflict of interest}

Authors would hereby like to declare that there is no conflict of interests that could possibly arise.

\section{References}

Acquaah G (2012) Principle of Plant Genetics and Breeding, second ed. Wiley-Black Well, ISBM: 978-0-470-66476-6.
Alhassan A, Salifu H, Adebanji AO (2016) Discriminant analysis of farmer's adoption of improved maize varieties in WA Municipality, Upper West Region of Ghana. Springer plus 5(1):1514. doi:10.1186/s40064-016-3196-z.

Araus JL, Slafer GA, Reynolds MP, Royo C (2009) Breeding for quantitative variables part \%: Breeding for yield potential. In: S Ceccarelli, Guimaraes EP, Weltzien E (Eds.) Plant breeding and farmer participation. Food Agriculture Organization of the United Nations, Rome, 2009.ISBM: 978-92-5-106382-8.

Aristil J, Pilu R, Spada A (2019) Morphological diversity among local and introduced maize (Zea mays L.) varieties in Haiti for yield improvement. Maydica 64(1). https://journalscrea.4science.it/index.php/maydica/article/view/1888/1206.

Bernardo R (2002) Breeding for quantitative traits in plants.Stemma Press, Woodberry, MN.

Betran JF, Banziger M, Menz M (2003) Pratical aspects of haploid production. In: Freeling M, Walbot V (eds) the Maize Handbook, Springer-Verlag, New York, pp. 386-388.

Bowman DT (2000) Attributes of public and private cotton breeding programs. Journal of Cotton Science 4:130-136.

Ceccarelli S (2009) Main stages of a plant breeding program. In: Ceccarelli S, Guimaraes EP, Weltzien E (Eds.) Plant Breeding and Farmer Participation. FAO, Rome, Italy, pp. 63-74. http://www.fao.org/3/i1070e/i1070e01.pdf.

Ceccarelli S, Grando S, Tutwiler R (2000) A Methodology Study on Participatory Barley Breeding. I. Selection Phase. Euphytica 111: 91104

CIMMYT (2014) CIMMYT releases 22 new maize inbred lines for the tropics and subtropics. Retrieved November 14, 2014, from http://www.cimmyt.org/en/what-we-do/maize-

research/item/cimmyt-releases-22- new-maize-inbred-lines-forthe-tropics-and-subtropics

Direction Statistique Agricole (2019) Ministère de la Production de l'Irrigation et des Equipement Agricole du Tchad. Rapport 2019

Fabunmi TO, Balogun RO (2015) Response of maize (Zea mays L.) to green manure from varying populations of cowpea in a derived savannah of Nigeria. African Journal of Food, Agriculture, Nutrition and Development 15 (3): 10138-10152.

Goldman I (2018) Plant Breeding Reviewing Vol. 41. Wiley Blackwell, Library of Congress Catalog Control Number: 83-641963.

Hancock JF (1992) Plant Evolution and Origin of Crop Species. Prentice-Hall Inc. A Simon \& Schuster Company, Englewood Cliffs, New Jersey, ISBN 0-13-678590-5. 
Ige SA, Aremu C, Abolusoro SA, bello O, Gbadamosi AA (2019) Genetic Variation, Heritability and Genetic Advance for Yield and Agronomic Traits Association of Some Low Nitrogen Tolerance Maize Varieties in the Tropics. International Journal of Civil Engineering and Technology (IJCIET) 10 (02): 1206-1216.

International Rice Research Institute (1996) IRRI toward 2020 Los Banos Philippines, IRRIS, Pp. 135.

Jackson P, Robertson M, Cooper M, Hammer G (1996) The role of physiological understanding in plant breeding; from a breeding perspective. Field Crops Research 49: 11-37.

Kande M, Ghimire SK, Ojha BR, Shrestha J (2017) Analysis of genetic diversity among the maize inbred lines (Zea mays L.) under heat stress condition. Journal of Maize Research and $\begin{array}{lllll}\text { Development } & 3 & \text { (1): } & 86-97 & \text { DOI }\end{array}$ http://dx.doi.org/10.3126/jmrd.v3i1.18925.

Mafouasson AHN, Kenga R, Gracen V, Yeboah AM, Mahamane NL, Tandzi NL, Ntsomboh-Ntsefong G (2017) Combining Ability and Gene Action of Tropical Maize (Zea mays L.) Inbred Lines under Low and High Nitrogen Conditions. Journal of Agricultural Science 9 (4). doi:10.5539/jas.v9n4p222.

Mushtaq M, Bhat MA, Bhat JA, Mukhtar S, Shah AA (2016) Comparative Analysis of Genetic Diversity of Maize Inbred Lines From Kashmir Valley Using agro-morphological and SSR Markers SABRAO. Journal of Breeding and Genetics 48 (4): 518-527.

Naitormmbaide M, Djondang K, Mama VJ, Koussou M (2015). Criblage de quelques variétés de maïs (Zea mays L.)pour la résistance au Striga hermonthica (Del) Benth dans les savanes tchadiennes. Journal of Animal \& Plant Sciences 24 (1) : 37223732, http://www.m.elewa.org/JAPS.

Okoli EE, Nworji MJ (2020). Evaluation of the performance of 21 maize hybrids (Zea mays L.) For yield and other agronomic attributes in Owerri West, South Eastern Nigeria. International Journal of Science, Environment and Technology 9 (2):136 - 147.

Piepho HP, Mohring J (2007) Computing heritability and selection response from unbalanced plant breeding trials. Genetics 177 (3):1881-1888. 